\title{
Prediction of Transient or Permanent Congenital Hypothyroidism
}

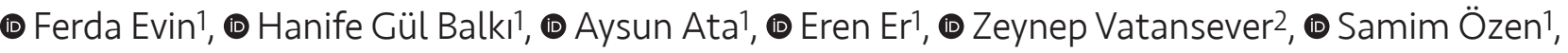 \\ (1) Damla Gökşen¹, (1) Şükran Darcan¹
}

${ }^{1}$ Ege University Faculty of Medicine, Department of Pediatrics, Division of Pediatric Endocrinology, İzmir, Turkey

${ }^{2}$ Ege University Faculty of Medicine, i̇zmir, Turkey

\begin{abstract}
Aim: Congenital hypothyroidism $(\mathrm{CH})$ is one of the most common endocrinological problems in the neonatal period. $\mathrm{CH}$, which occurs in 1:3,000-4,000 births, is a preventable cause of mental retardation. In the literature, the most common cause of $\mathrm{CH}$ is dysgenesis of the thyroid gland, followed by thyroid dyshormonogenesis. We aimed to determine the prevalence of permanent (P-CH) and transient $(\mathrm{T}-\mathrm{CH}) \mathrm{CH}$ in cases followed up with a diagnosis of $\mathrm{CH}$ and to identify a prediction method for persistency.
\end{abstract}

Materials and Methods: We retrospectively analyzed the medical records of 105 children with $\mathrm{CH}$. TSH levels in a screening program, TSH and fT 4 levels of the first venous sample, $10-15^{\text {th }}$ day of treatment, monthly in the first 6 months, 2-3 monthly until $18^{\text {th }}$ months, and 6-monthly until 3 years of age were recorded. L-T4 doses (per microgram per body weight) in each visit were also recorded.

Results: From the 105 children (58 males, 47 females) enrolled in this study, 38 (36.2 \%) were referred from the National Newborn Screening Program. Treatment was discontinued during the $3^{\text {rd }}$ year follow-up period in 44 (41.9\%) of the cases with normal thyroid gland morphology. L-thyroxine (L-T4) therapy was discontinued at a median age of 1.9+-1.08 years.TSH levels at the time of diagnosis were higher in the $\mathrm{P}$ - $\mathrm{CH}$ group, but this difference was not statistically significant $(p=0.165)$.

At the sixth month, first and second years of follow-up, L-T4 doses were significantly higher in the P-CH than in the T-CH group ( $p<0.001$, $p<0.001, p<0.001$ respectively). TSH levels were also higher in the $\mathrm{P}-\mathrm{CH}$ group than in the $\mathrm{T}-\mathrm{CH}$ group $(p=0.123, p=0.038, p=0.049$ respectively). Consistent with these results, measured fT4 levels were found to be lower in the $\mathrm{P}-\mathrm{CH}$ group compared to the T-CH group $(p=0.431, p=0.361$, $\mathrm{p}=0.028$ respectively).

Conclusion: L-T4 doses at 6, 12 and 24 months may predict transient hypothyroidism in patients with normal thyroid gland morphology before 36 months.

Keywords: Congenital hypothyroidism, dyshormonogenesis, screening, thyroid dysgenesis, permanent hypothyroidism, transient hypothyroidism 


\section{Introduction}

Congenital hypothyroidism $(\mathrm{CH})$ is one of the most common endocrinological problems in the neonatal period. $\mathrm{CH}$, which occurs in 1:3,000 to 4,000 live births, is a preventable cause of mental retardation. In a study from Turkey, its prevalence was $1 / 2,525(1,2)$. $\mathrm{CH}$ is two times more common in girls than in boys and is classified into 2 types: permanent $\mathrm{CH}(\mathrm{P}-\mathrm{CH})$ and transient $\mathrm{CH}(\mathrm{T}-\mathrm{CH})$. $\mathrm{P}-\mathrm{CH}$ requires life-long levo-thyroxine (L-T4) treatment whereas $\mathrm{T}-\mathrm{CH}$ shows continuous, normal thyroid function after discontinuation of LT4 treatment. Although the distinction between $\mathrm{P}-\mathrm{CH}$ and $\mathrm{T}-\mathrm{CH}$ is clinically one of the most important concerns for the parents of affected children, differentiating between the 2 types in the neonatal period is difficult, and LT4 treatment should be prioritized to avoid mental retardation (3). The majority of $\mathrm{P}-\mathrm{CH}$ cases were thyroid dysgenesis; followed by ectopic thyroid gland and aplasia/hypoplasia (4). Only $15 \%$ of $\mathrm{P}-\mathrm{CH}$ cases were thyroid dyshormonogenesis (5). T- $\mathrm{CH}$ includes; iodine deficiency, excessive iodine exposure, thyroid stimulating hormone (TSH) receptor blocking antibodies transmitted from mother to fetus, and maternal usage of antithyroid drugs (2).

$\mathrm{CH}$ is one of the most important causes of preventable mental retardation and constitutes a serious public health problem. Many developed countries have largely eliminated intellectual disability caused by $\mathrm{CH}$ owing to newborn screening programs (NSPs) (1). In Turkey, the National NSP (NNSP) for CH (dried blood spot at 48-72 hours of life) was started on December 26, 2006 by the Turkish Directorate of Public Health. According to the NNSP, an infant is considered to have passed the screening test when the blood spot TSH is $<5.5 \mathrm{mIU} / \mathrm{L}$. Values between $5.5 \mathrm{mU} / \mathrm{L}$ and $20 \mathrm{mIU} / \mathrm{L}$, are reported for a second evaluation. All cases with a capillary TSH concentration above $5.5 \mathrm{mlU} / \mathrm{L}$ in repeat blood samples or above $20 \mathrm{mIU} / \mathrm{L}$ in the first sample are referred to the appropriate center for evaluation by venous thyroid function testing, including free thyroxine (fT4) and TSH.

In the present study, we retrospectively analyzed $\mathrm{CH}$ cases from the neonatal period up to three years of age in order to determine the prevalence of permanent and transient $\mathrm{CH}$.

\section{Materials and Methods}

\section{Study Population and Design}

This retrospective design study included patients referred from the NNSP and patients diagnosed with $\mathrm{CH}$ at Ege University Pediatric Endocrinology Clinic between January 1 $1^{\text {st }}, 2014$ and December 31 th, 2017 . CH was diagnosed if TSH was $>10 \mu \mathrm{IU} / \mathrm{mL}$ within the first month of life, with low/normal fT4 levels. Patients who were diagnosed in other hospitals, who had premature delivery history, whose first thyroid function tests were unknown, whose treatment was started in other hospitals or who were not followed up for three years for various reasons were excluded from this analysis. Cases with central hypothyroidism were not included in the study.

Demographic measures, auxological measurements, date of birth, admission age, postnatal age, gender, gestational age in weeks and maternal thyroid disease history were extracted from the systematically collected medical records. Other concomitant congenital diseases were recorded. All weight and height standard deviation (SD) score calculations were made by an automatic calculator (3).

TSH levels in a screening program, TSH and fT4 levels of the first venous sample, $10-15^{\text {th }}$ day of treatment, monthly in the first 6 months, $2-3$ monthly until $18^{\text {th }}$ months, and 6-monthly until 3 years of age were recorded. L-T4 doses (per microgram per body weight) in each visit were also recorded. Four and six weeks after the treatment was discontinued, TFT and fT4 were re-evaluated. All serum fT4 and TSH concentrations were measured at least 4 hours after the last L-thyroxine administration.

Thyroid ultrasonography (USC) was performed in all patients. Thyroid glands with a volume less than $0.64 \mathrm{~mL}$ $\left(10^{\text {th }}\right.$ percentile) were considered to be hypoplastic for the neonatal period, and those with a volume greater than $1.15 \mathrm{~mL}$ ( $95^{\text {th }}$ percentile) were considered to be hyperplasic (4). Thyroid scintigraphy was performed in those patients whose thyroid gland could not be visualized by USG. According to thyroid imaging results; thyroid glands were classified as agenesis, hemiagenesis, ectopia, hypoplasia or normal.

Cases with normal thyroid appearance were accepted as thyroid dyshormonogenesis, and other cases were accepted as thyroid dysgenesis. In those patients with normal thyroid gland; discontinuation of treatment was tried at any time until the age of 3, and then having TSH $<10 \mathrm{mIU} / \mathrm{mL}$ and normal fT4 level for at least 6 months were classified as transient hypothyroidism. Patients with thyroid dysgenesis and/or continued treatment at the end of the third year were classified as permanent hypothyroidism. 
Those children who gave assent and whose parents gave signed consent were enrolled in the study. The study was approved by the Ege University Medical Ethics Committee with approval number: 20-12T/24.

\section{Laboratory Methods}

Serum TSH and fT4 levels were measured by electrochemiluminescence immunoassay using Elecsys 2010 modular analytics E170 (Roche Diagnostics, Indianapolis, IN, USA). For cases between 6 days and 3 months; the normal range of TSH is $0.72-11.0 \mu \mathrm{U} / \mathrm{mL}$, and for fT4, it is $0.9-2.2$ $\mathrm{ng} / \mathrm{dL}$. For older cases; TSH level were considered normal if between 0.27-4.2 $\mu \mathrm{lU} / \mathrm{mL}$, and fT4 level was considered normal if between 1.1-2.1 ng/dL.

\section{Statistical Analysis}

Analysis was carried out using SPSS for windows 25.0, descriptive statistics are reported using mean \pm SD for normally distributed variables, and median for skewed data. Groups were compared by independent samples t-test for normally distributed variables and the Mann-Whitney $U$ test for skewed data. Trends across time were analyzed using linear polynomial contrasts (ANOVA). A p-value $<0.05$ was considered statistically significant, no adjustment was made for multiplicity of statistical tests.

\section{Results}

Out of 192 (101 females, 91 males) patients, 105 patients who met the study criteria were enrolled. Out of these 105 patients, 58 (55.2\%) were male, and 47 (44.8\%), were female. A history of maternal autoimmune thyroid disease was positive in 34 (32.4\%) patients. Mean gestational age was $38.82 \pm 1.42$ weeks, and mean birth weight was $3,167 \pm 551$ gr. The mean age at diagnosis was $22.3 \pm 21.9$ days. The mean serum TSH level was $85.08 \pm 65.60(2.64-501) \mu \mathrm{IU} / \mathrm{mL}$, and the mean fT4 level was $0.96 \pm 0.35(0.14-1.67) \mathrm{ng} / \mathrm{dL}$ in all patients at admission. Mean screening capillary TSH was $66.30 \pm 48.50 \mu \mathrm{lU} / \mathrm{mL}$, first venous TSH was $90.87 \pm 82.48$ $(7.4-498) \mu \mathrm{IU} / \mathrm{mL}$ and first venous fT4 level was $0.87 \pm 0.34$ (0.23-1.67) $\mathrm{ng} / \mathrm{dL}$ in those patients who were referred from the NNSP ( $n=38 ; 36.2 \%)$. In the remaining 67 (63.8\%) patients, venous TSH levels, obtained for various reasons, were high.

Thyroid USG was performed in all patients. Based on the findings of thyroid imaging, the morphology of the thyroid glands was classified as follows: 1 (0.9\%) hemiagenesis, 3 (2.8\%) hypoplasia and 94 (89.5\%) of normal morphology (Table I). In 7 (6.6\%) cases, the thyroid gland was not visualized in the normal location and thyroid scintigraphy was performed. Four of these patients had sublingual ectopic thyroid gland and three of them had agenesis on thyroid scintigraphy.

Treatment was discontinued during the 3-year followup period in $44(41.9 \%)$ cases with normal thyroid gland morphology. L-T4 therapy was discontinued at a median age of $1.9 \pm 1.08$ years. The mean serum TSH level was $3.04 \pm 1.17$ $\mu \mathrm{IU} / \mathrm{mL}$, and the mean fT4 level was $1.37 \pm 0.30 \mathrm{ng} / \mathrm{dL}$ at the time of discontinuation. The last dose of L-T4 treatment used was $1.24 \pm 0.45 \mathrm{mcg} / \mathrm{kg} /$ day.

At the time of diagnosis, fT4 levels were significantly higher in the $\mathrm{T}-\mathrm{CH}$ group than in the $\mathrm{P}-\mathrm{CH}$ group, including thyroid dysgenesis $(p=0.037)$. TSH levels at the time of diagnosis were higher in the $\mathrm{P}-\mathrm{CH}$ group than in the $\mathrm{T}-\mathrm{CH}$ group, but this difference was not statistically significant $(p=0.165)$. No significant difference was found between the auxological measurement of $\mathrm{T}-\mathrm{CH}$ and $\mathrm{P}-\mathrm{CH}$ patients. The laboratory and auxological measurements of the patients with permanent and transient $\mathrm{CH}$ at the time of diagnosed are summarized in Table II. In the $\mathrm{P}-\mathrm{CH}$ group; TSH values measured in the early period $\left(1^{\text {st }}, 2^{\text {nd }}\right.$ and $3^{\text {rd }}$ months) were lower and fT4 values were higher. However, this difference was not statistically significant (Table III).

\begin{tabular}{|c|c|c|}
\hline & Appearance (n) & Rate (\%) \\
\hline Normal thyroid glang morphology & 94 & 89.5 \\
\hline Hypoplastic gland & 3 & 2.8 \\
\hline Hemiagenesis of the gland & 1 & 0.9 \\
\hline $\begin{array}{l}\text { Not visualized in the normal } \\
\text { location (ectopy/agenesis) }\end{array}$ & 7 & 6.6 \\
\hline
\end{tabular}

Table II. Baseline characteristics of infants with permanent and transient congenital hypothyroidism

\begin{tabular}{|c|c|c|c|}
\hline Parameter & $\begin{array}{l}\text { Permanent } \\
\mathrm{CH}(n=61)\end{array}$ & $\begin{array}{l}\text { Transient } \\
\mathrm{CH}(n=44)\end{array}$ & p-value \\
\hline $\begin{array}{l}\text { TSH levels } \\
(\mathrm{N}: 0.27-4.2 \mathrm{mIU} / \mathrm{mL})\end{array}$ & $97.11 \pm 76.40$ & $63.22 \pm 50.84$ & 0.165 \\
\hline $\begin{array}{l}\text { fT4 levels } \\
\text { (N: } 1.1-2.1 \mathrm{ng} / \mathrm{dL})\end{array}$ & $0.90 \pm 0.35$ & $1.04 \pm 0.33$ & 0.03 \\
\hline $\begin{array}{l}\mathrm{L}-\mathrm{T} 4 \text { dose at onset (mcg/ } \\
\mathrm{kg} / \text { day) }\end{array}$ & $8.68 \pm 3.54$ & $8.01 \pm 3.22$ & 0.322 \\
\hline Weight SDS & $-0.45 \pm 1.31$ & $-0.57 \pm 1.19$ & 0.631 \\
\hline Height SDS & $-0.46 \pm 1.29$ & $-0.46 \pm 0.81$ & 0.983 \\
\hline
\end{tabular}


At the sixth month follow-up, first year follow-up and second year follow-up, L-T4 doses were significantly higher, TSH levels were significantly higher, and serum fT4 levels were significantly lower in in the $\mathrm{P}-\mathrm{CH}$ group than the T-CH group (Table IV). The LT4 dosage cut-off by receiver operating characteristic (ROC) curve analysis was 1.96 [with sensitivity at $73 \%$ and specificity at $82 \%$, area under the curve $(A \cup C)=0.82$ ], 1.56 (with sensitivity at $73 \%$, specificity at $73 \%, A \cup C=0.76)$, and $1.24 \mu \mathrm{g} / \mathrm{kg} / \mathrm{day}$ [with sensitivity at $85 \%$, specificity at $73 \%, A U C=0.84$ ) at ages 1,2 , and 3 years, respectively. The ROC curve is shown in Figure 1.

In subgroup analysis, those cases with thyroid dysgenesis were excluded and the remaining cases were examined in 2 groups as either permanent or transient dyshormonogenesis. There was no significant difference in the TSH, fT4 levels and L-T4 doses at the time of diagnosis between these groups $(p=0.424, p=0.069$ and $p=0.589$ respectively) (Table $V$ ). At the six-month, oneyear and two-year follow-up, L-T4 doses were higher in the permanent dyshormonogenesis group than in the transient dyshormonogenesis group $(p=0.020, p=0.015$, $\mathrm{p}=0.143$ respectively) (Table $\mathrm{VI})$.

Two cases (1.9\%) were Down syndrome and both of these cases had dyshormonogenesis. Fifteen (14.2\%) cases had a history of concomitant congenital disease. The most common congenital disease was congenital heart disease (46.6\%) (Table VII). Two of the patients (13.3\%) with concomitant congenital disease had thyroid dysgenesis, while the others had dyshormonogenesis.

Table III. First, $2^{\text {nd }}$ and $3^{\text {th }}$ month laboratory data of permanent and transient $\mathrm{CH}$ cases

\begin{tabular}{|l|l|l|l|}
\hline Parameter & $\begin{array}{l}\text { Permanent } \\
\text { CH } \\
\text { (n=61) }\end{array}$ & $\begin{array}{l}\text { Transient } \\
\mathbf{C H} \\
\mathbf{( n = 4 4 )}\end{array}$ & p-value \\
\hline $\begin{array}{l}1^{\text {st }} \text { month TSH levels } \\
(\mathrm{N}: 0.27-4.2 \mathrm{mlU} / \mathrm{mL})\end{array}$ & $3.75 \pm 2.77$ & $2.00 \pm 1.63$ & 0.529 \\
\hline $\begin{array}{l}1^{\text {st }} \text { month fT4 levels } \\
(\mathrm{N}: 1.1-2.1 \mathrm{ng} / \mathrm{dL})\end{array}$ & $1.70 \pm 0.51$ & $1.66 \pm 0.45$ & 0.731 \\
\hline $\begin{array}{l}2^{\text {nd }} \text { month TSH Levels } \\
(\mathrm{N}: 0.27-4.2 \mathrm{mlU} / \mathrm{mL})\end{array}$ & $2.51 \pm 1.51$ & $1.35 \pm 1.07$ & 0.140 \\
\hline $\begin{array}{l}2^{\text {nd }} \text { month } \mathrm{fT} 4 \text { levels } \\
(\mathrm{N}: 1.1-2.1 \mathrm{ng} / \mathrm{dL})\end{array}$ & $1.56 \pm 0.35$ & $1.51 \pm 0.29$ & 0.544 \\
\hline $\begin{array}{l}3^{\text {th }} \text { month TSH levels } \\
(\mathrm{N}: 0.27-4.2 \mathrm{mlU} / \mathrm{mL})\end{array}$ & $3.67 \pm 2.71$ & $1.83 \pm 1.57$ & 0.194 \\
\hline $\begin{array}{l}3^{\text {th }} \text { month } \mathrm{fT} 4 \text { levels } \\
\text { (N: } 1.1-2.1 \mathrm{ng} / \mathrm{dL})\end{array}$ & $1.44 \pm 0.30$ & $1.48 \pm 0.24$ & 0.561 \\
\hline $\begin{array}{l}\text { CH: Congenital hypothyroidism, TSH: Thyroid stimulating hormone, fT4: Free } \\
\text { thyroxine }\end{array}$ \\
\hline
\end{tabular}

\section{Discussion}

Our cross-sectional study is one of the most comprehensive retrospective analyzes performed on a national basis to evaluate the data of those cases with either transient or permanent hypothyroidism. Several authors have proposed numerous distinguishing factors between $\mathrm{P}-\mathrm{CH}$ and $\mathrm{T}-\mathrm{CH}$; however, markers for the early detection of T-CH have yet to be validated (5-9).

In studies of $\mathrm{CH}, \mathrm{P}-\mathrm{CH}$ is more frequent than $\mathrm{T}-\mathrm{CH}$. In Hashemipour et al.'s (10) study, the prevalence of P-CH was $59.8 \%$, while Scavone et al. (11) reported it to be $65.5 \%$. In a study conducted in Turkey in which 189 cases were analyzed, the prevalence of P-CH was $53.2 \%$ (10), while in another study, it was 54 (5). Yanmaz et al. (12) showed a $\mathrm{P}-\mathrm{CH}$ rate of $41.5 \%$, and they thought that this low frequency may be due to the high consanguineous marriage rate in the study population region. In our study, the rate of permanent hypothyroidism was $58 \%$, and this was similar to other studies in the literature.

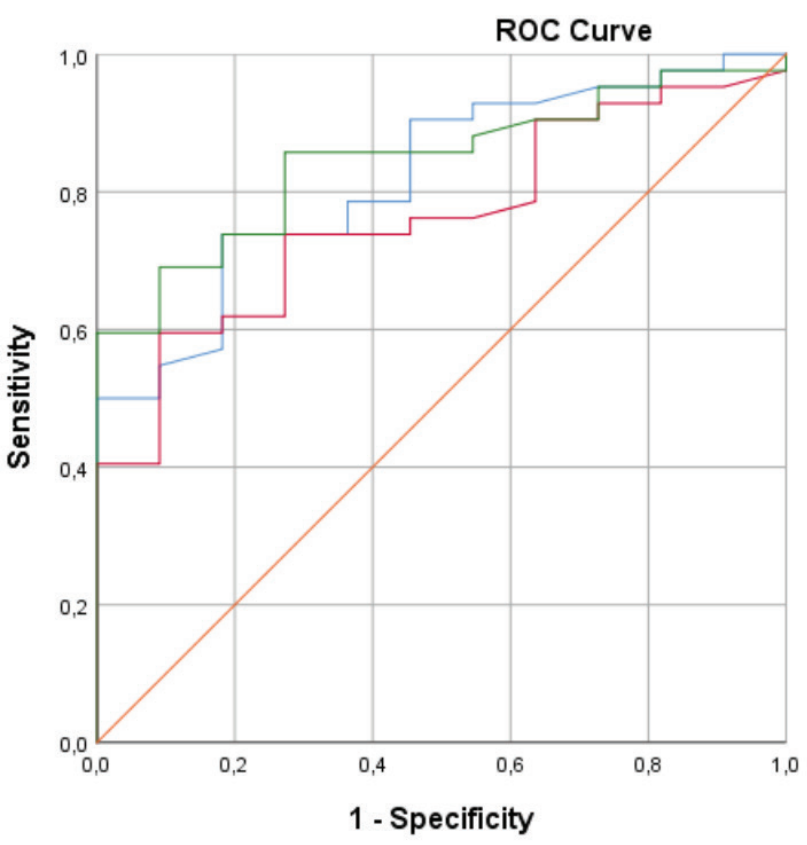

Diagonal segments are produced by ties.

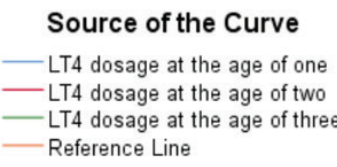

Figure 1. ROC curve of $L T 4$ dosages ROC: Receiver operator characteristic 
Traditionally, it is known that $85 \%$ of $\mathrm{CH}$ is dysgenesis and $15 \%$ is dyshormonogenesis. In our study, thyroid dysgenesis was $18 \%$ of the permanent hypothyroidism, much lower than expected. Similar to our study, Kara et al. (13) reported this rate to be $61 \%$, and Bezen et al. (14) reported it to be $56.5 \%$. In similar studies in the literature, this rate was reported to be $50-85 \%(2,5,7,11)$. However, in a study by Donbaloğlu et al. (15), the rate of thyroid dysgenesis was $33.3 \%$. In a multi-center study conducted in China, 829 cases detected in $\mathrm{CH}$ screening were analyzed retrospectively; thyroid imaging was performed in 664 $(80.1 \%)$ and thyroid dysgenesis was found in 194 (29.2\%) cases (16).

In a study from Japan, 99 cases were analyzed for TSH level and L-T4 dose at the time of diagnosis. These parameters were higher in the $\mathrm{P}-\mathrm{CH}$ group (17). In our study group, in accordance with this data in the literature, the fT4 level at the time of diagnosis was

\begin{tabular}{|c|c|c|c|}
\hline Parameter & $\begin{array}{l}\text { Permanent CH } \\
(n=61)\end{array}$ & $\begin{array}{l}\text { Transient CH } \\
(n=44)\end{array}$ & p-value \\
\hline $\begin{array}{l}6^{\text {th }} \text { month TSH levels } \\
(\mathrm{N}: 0.27-4.2 \mathrm{mIU} / \mathrm{mL})\end{array}$ & $5.91 \pm 3.62$ & $1.97 \pm 0.97$ & 0.123 \\
\hline $\begin{array}{l}6^{\text {th }} \text { month fT4 levels } \\
(\mathrm{N}: 1.1-2.1 \mathrm{ng} / \mathrm{dL})\end{array}$ & $1.52 \pm 0.70$ & $1.64 \pm 0.76$ & 0.431 \\
\hline $6^{\text {th }}$ month L-T4 dose (mcg/kg/day) & $2.74 \pm 1.02$ & $1.98 \pm 0.94$ & 0.000 \\
\hline $6^{\text {th }}$ month weight SDS & $-0.21 \pm 1.25$ & $-0.01 \pm 0.94$ & 0.430 \\
\hline $6^{\text {th }}$ month height SDS & $-0.23 \pm 1.28$ & $-0.04 \pm 0.94$ & 0.346 \\
\hline $\begin{array}{l}12^{\text {th }} \text { month TSH Levels } \\
(\mathrm{N}: 0.27-4.2 \mathrm{mlU} / \mathrm{mL})\end{array}$ & $4.24 \pm 4.02$ & $2.29 \pm 1.09$ & 0.038 \\
\hline $\begin{array}{l}12^{\text {th }} \text { month fT4 levels } \\
(\mathrm{N}: 1.1-2.1 \mathrm{ng} / \mathrm{dL})\end{array}$ & $1.35 \pm 0.24$ & $1.40 \pm 0.23$ & 0.361 \\
\hline $12^{\text {th }}$ month L-T4 dose (mcg/kg/day) & $2.42 \pm 0.97$ & $1.72 \pm 0.45$ & 0.000 \\
\hline $12^{\text {th }}$ month weight SDS & $-0.23 \pm 1.17$ & $-0.23 \pm 0.83$ & 0.774 \\
\hline $12^{\text {th }}$ month height SDS & $-0.18 \pm 1.13$ & $-0.12 \pm 1.02$ & 0.794 \\
\hline $\begin{array}{l}24^{\text {th }} \text { month TSH Levels } \\
(\mathrm{N}: 0.27-4.2 \mathrm{mIU} / \mathrm{mL})\end{array}$ & $4.29 \pm 4.27$ & $2.71 \pm 1.26$ & 0.490 \\
\hline $\begin{array}{l}24^{\text {th }} \text { month fT4 levels } \\
(\mathrm{N}: 1.1-2.1 \mathrm{ng} / \mathrm{dL})\end{array}$ & $1.41 \pm 0.21$ & $1.30 \pm 0.21$ & 0.028 \\
\hline $24^{\text {th }}$ month L-T4 dose (mcg/kg/day) & $2.24 \pm 1.28$ & $1.50 \pm 0.39$ & 0.009 \\
\hline $24^{\text {th }}$ month weight SDS & $-0.22 \pm 1.25$ & $-0.09 \pm 1.26$ & 0.289 \\
\hline $24^{\text {th }}$ month height SDS & $-0.52 \pm 1.20$ & $-0.31 \pm 0.87$ & 0.446 \\
\hline
\end{tabular}

Table V. Baseline characteristics of infants with permanent and transient dyshormonogenesis cases

\begin{tabular}{|l|l|l|l|}
\hline Parameter & $\begin{array}{l}\text { Permanent dyshormonogenesis } \\
\text { cases }(\mathbf{n}=\mathbf{5 0})\end{array}$ & $\begin{array}{l}\text { Transient dyshormonogenesis cases } \\
\text { (n=44) }\end{array}$ & p-value \\
\hline $\begin{array}{l}\text { TSH levels } \\
(\mathrm{N}: 0.27-4.2 \mathrm{mIU} / \mathrm{mL})\end{array}$ & $82.8 \pm 63.8$ & $63.8 \pm 51.3$ & 0.424 \\
\hline $\begin{array}{l}\text { fT4 levels } \\
(\mathrm{N}: 1.1-2.1 \mathrm{ng} / \mathrm{dL})\end{array}$ & $0.92 \pm 0.35$ & $1.04 \pm 0.33$ & 0.069 \\
\hline L-T4 dose at onset $(\mathrm{mcg} / \mathrm{kg} /$ day) & $8.42 \pm 3.53$ & $8.04 \pm 3.26$ & 0.589 \\
\hline Weight SDS & $-0.43 \pm 1.35$ & $-0.62 \pm 1.17$ & 0.472 \\
\hline Height SDS & $-0.4 \pm 1.30$ & $-0.45 \pm 0.82$ & 0.676 \\
\hline TSH: Thyroid stimulating hormone, fT4: Free thyroxine, L-T4: Levo-thyroxine, SDS: Standard deviation score & \\
\hline
\end{tabular}




\begin{tabular}{|c|c|c|c|}
\hline & $\begin{array}{l}\text { Permanent dyshormonogenesis } \\
\text { cases }(n=50)\end{array}$ & $\begin{array}{l}\text { Transient dyshormonogenesis } \\
\text { cases }(n=44)\end{array}$ & p-value \\
\hline Parameter & $2.97 \pm 2.68$ & $1.99 \pm 0.97$ & 0.391 \\
\hline $\begin{array}{l}6^{\text {th }} \text { month TSH levels } \\
(\mathrm{N}: 0.27-4.2 \mathrm{mIU} / \mathrm{mL})\end{array}$ & $1.54 \pm 0.77$ & $1.65 \pm 0.76$ & 0.506 \\
\hline $\begin{array}{l}6^{\text {th }} \text { month fT4 levels } \\
(\mathrm{N}: 1.1-2.1 \mathrm{ng} / \mathrm{dL})\end{array}$ & $2.70 \pm 1.05$ & $2.00 \pm 0.95$ & 0.002 \\
\hline $6^{\text {th }}$ month L-T4 dose (mcg/kg/day) & $1.18 \pm 0.24$ & $0.97 \pm 0.01$ & 0.559 \\
\hline $6^{\text {th }}$ month weight SDS & $-0.15 \pm 1.18$ & $-0.01 \pm 0.94$ & 0.447 \\
\hline $6^{\text {th }}$ month height SDS & $3.98 \pm 3.84$ & $2.37 \pm 1.02$ & 0.417 \\
\hline $\begin{array}{l}12^{\text {th }} \text { month TSH levels } \\
(\mathrm{N}: 0.27-4.2 \mathrm{mIU} / \mathrm{mL})\end{array}$ & $1.32 \pm 0.20$ & $1.40 \pm 0.23$ & 0.112 \\
\hline $\begin{array}{l}12^{\text {th }} \text { month fT4 levels } \\
(\mathrm{N}: 1.1-2.1 \mathrm{ng} / \mathrm{dL})\end{array}$ & $2.29 \pm 0.88$ & $1.74 \pm 0.45$ & 0.015 \\
\hline $12^{\text {th }}$ month L-T4 dose (mcg/kg/day) & $1.20 \pm 0.35$ & $0.84 \pm 0.23$ & 0.586 \\
\hline $12^{\text {th }}$ month weight SDS & $-0.25 \pm 1.20$ & $-0.17 \pm 0.99$ & 0.751 \\
\hline $12^{\text {th }}$ month height SDS & $4.47 \pm 4.39$ & $2.77 \pm 1.23$ & 0.660 \\
\hline $\begin{array}{l}24^{\text {th }} \text { month TSH levels } \\
(\mathrm{N}: 0.27-4.2 \mathrm{mIU} / \mathrm{mL})\end{array}$ & $1.42 \pm 0.22$ & $1.31 \pm 0.21$ & 0.042 \\
\hline $\begin{array}{l}24^{\text {th }} \text { month fT4 levels } \\
(\mathrm{N}: 1.1-2.1 \mathrm{ng} / \mathrm{dL})\end{array}$ & $2.01 \pm 1.01$ & $1.47 \pm 0.36$ & 0.143 \\
\hline $24^{\text {th }}$ month L-T4 dose (mcg/kg/day) & $1.17 \pm 0.19$ & $1.28 \pm 0.10$ & 0.313 \\
\hline $24^{\text {th }}$ month weight SDS & $-0.48 \pm 1.07$ & $-0.33 \pm 0.88$ & 0.559 \\
\hline
\end{tabular}

Table VII. Congenital anomalies accompanying congenital hypothyroidism

\begin{tabular}{|l|l|l|}
\hline & Number & Rate (\%) \\
\hline Tetralogy of Fallot & 2 & 13.3 \\
\hline Pulmonary stenosis & 2 & 13.3 \\
\hline Aortic coarctation & 1 & 6.6 \\
\hline Atrioventricular septal defect & 1 & 6.6 \\
\hline Double outlet right ventricle & 1 & 6.6 \\
\hline Cleft palate & 1 & 6.6 \\
\hline Tracheoesophageal fistula & 2 & 13.3 \\
\hline Duodenal atresia & 1 & 6.6 \\
\hline Anal atresia & 1 & 6.6 \\
\hline Horseshoe kidney & 1 & 6.6 \\
\hline Posterior urethral valve & 1 & 6.6 \\
\hline Meningomyelocele & 1 & 6.6 \\
\hline
\end{tabular}

significantly lower in the $\mathrm{P}-\mathrm{CH}$ group compared to the T$\mathrm{CH}$ group. However, the TSH levels and L-T4 doses were not statistically significant higher in the $\mathrm{P}-\mathrm{CH}$ group as was seen in several other studies $(6,18)$. Similarly, Tamam et al. (19) reported that TSH levels were significantly higher and fT4 levels were significantly lower at the time of diagnosis in the $\mathrm{P}-\mathrm{CH}$ group than in the $\mathrm{T}-\mathrm{CH}$ group. In another study, fT4 levels were lower in patients with $\mathrm{P}$ - $\mathrm{CH}$ in accordance with the etiology of the patients (12). In a study from Brazil, it was shown that initial TSH levels cannot be determinative in making a distinction between the transient and permanent disease types (20).

Itonaga et al. (17) reported that the dose of L-T4 used in the first and second years of follow-up was higher in the $\mathrm{P}-\mathrm{CH}$ group. Furthermore, they showed that $\mathrm{CH}$ patients with an LT4 dosage $>3.26 \mu \mathrm{g} / \mathrm{kg} /$ day at age 1 year, $>2.29$ $\mu \mathrm{g} / \mathrm{kg} /$ day at age 2 years and $>2.32 \mu \mathrm{g} / \mathrm{kg} /$ day at age 3 years were likely to have P-CH (17). In a study in Turkey, drug doses in the sixth month, first and second year were significantly higher in the P-CH group (12). In our study, 
similar to the literature, LT4 doses at the sixth month, first and second year were significantly higher in the $\mathrm{P}-\mathrm{CH}$ group. The cut-off values we obtained were similar to other studies $(6,17)$. However, although those patients in the $\mathrm{P}-\mathrm{CH}$ group used higher doses of medication, their first and second year TSH levels were higher than the $\mathrm{T}-\mathrm{CH}$ group. This finding is not expected under appropriate treatment and we speculate that there may have been problems with treatment compliance.

\section{Study Limitations}

Our study has some limitations such as its retrospective design, no free T3 levels, thyroglobulin and urine iodine levels and the lack of complete data regarding maternal drug intake and the use of iodine during delivery.

\section{Conclusion}

Our cross-sectional retrospective study is one of the comprehensive analysis performed on a national basis to evaluate the data of cases with transient or permanent hypothyroidism. We are conscious that these results will not modify the current standard of practice but we believe that our data, supported by other studies, may allow for earlier discrimination between $\mathrm{T}-\mathrm{CH}$ and $\mathrm{P}-\mathrm{CH}$. In conclusion, the results of this study show that fT4 levels at diagnosis and the L-thyroxine dose at the sixth month, first and second year can be used to distinguish between $\mathrm{T}-\mathrm{CH}$ and $\mathrm{P}-\mathrm{CH}$.

\section{Ethics}

Ethics Committee Approval: The study was approved by the Ege University Medical Ethics Committee with approval number: 20-12T/24.

Informed Consent: Those children who gave assent and whose parents gave signed consent were enrolled in the study.

Peer-review: Externally and internally peer-reviewed.

\section{Authorship Contributions}

Concept: F.E., Design: F.E., S.Ö., Data Collection or Processing: H.G.B., A.A., E.E., Analysis or Interpretation: H.G.B., A.A., E.E., Z.V., Literature Search: S.Ö., D.G., Project Administration: Ş.D., Writing: F.E., H.G.B., A.A., E.E., D.G.

Conflict of Interest: The authors declared no conflict of interest.

Financial Disclosure: The authors declared that this study received no financial support.

\section{References}

1. Mass Screening Committee; Japanese Society for Pediatric Endocrinology; lapanese Society for Mass Screening, Nagasaki K, Minamitani $\mathrm{K}$, et al. Guidelines for mass screening of congenital hypothyroidism (2014 revision). Clin Pediatr Endocrinol 2015; 24:107-33.

2. LaFranchi SH. Approach to the diagnosis and treatment of neonatal hypothyroidism. I Clin Endocrinol Metab 2011; 96:2959-67.

3. Demir K, Konakçı E, Özkaya G, et al. New features for child metrics: Further growth references and blood pressure calculations. J Clin Res Pediatr Endocrinol 2020; 12:125-9.

4. Köksal N, Aktürk B, Sağlam H, Yazıcı Z, Çetinkaya M. Reference values for neonatal thyroid volumes in a moderately iodinedeficient area. J Endocrinol Invest 2008; 31:642-6.

5. Ünüvar $T$, Demir K, Abacı A, Büyükgebiz A, Böber $E$. The role of initial clinical and laboratory findings in infants with hyperthyrotropinemia to predict transient or permanent hypothyroidism. I Clin Res Pediatr Endocrinol 2013; 5:170-3.

6. Messina MF, Aversa T, Salzano G, et al. Early discrimination between transient and permanent congenital hypothyroidism in children with eutopic gland. Horm Res Paediatr 2015; 84:159-64.

7. Srinivasan R, Harigopal S, Turner S, Cheetham T. Permanent and transient congenital hypothyroidism in preterm infants. Acta Paediatr 2012; 101:179-82

8. Kravarusic ). Diabetes Technology Use in Adult swith Type 1 and Type 2 Diabetes. Endocrinol Metab Clin North Am 2020; 49:37-55.

9. Chung HR, Shin $\mathrm{CH}$, Yang SW, et al. High incidence of thyroid dysfunction in preterm infants. I Korean Med Sci 2009; 24:62731.

10. Hashemipour M, Hovsepian S, Kelishadi R, et al. Permanent and transient congenital hypothyroidism in Isfahan-Iran. I Med Screen 2009; 16:11-6.

11. Scavone M, Carboni E, Stefanelli E, et al. Prediction of Transient or Permanent Congenital Hypothyroidism from Initial Thyroid Stimulating Hormone Levels. Indian Pediatr 2018; 55:1059-61.

12. Yanmaz SY, Ünal E, Taş FF, Yıldııım R, Haspolat YK. Characteristics of Patients with Congenital Hypothyroidism. J Curr Pediatr 2019; 17:412-23.

13. Kara C, Günindi F, Can Yılmaz G, Aydın M. Transient congenital hypothyroidism in Turkey: An analysis on frequency and natural course. J Clin Res Pediatr Endocrinol 2016; 8:170-9.

14. Bezen D, Dilek E, Torun N, Tütüncüler F. Etiological evaluation of primary congenital hypothyroidism cases. Turk Pediatr Ars 2017; 52:85-91.

15. Donbaloğlu Z, Savaş-Erdeve Ş, Çetinkaya S, Aycan Z. Cases referred from the turkish national screening program: Frequency of congenital hypothyroidism and etiological distribution. I Clin Res Pediatr Endocrinol 2019; 11:240-6.

16. Chen J, Lin S, Zeng G, et al. Epidemiologic characteristics and risk factors for congenital hypothyroidism from 2009 to 2018 in Xiamen, China. Endocr Pract 2020; 26:585-94.

17. Itonaga T, Higuchi S, Shimura $\mathrm{K}$, et al. Levothyroxine Dosage as Predictor of Permanent and Transient Congenital Hypothyroidism: A Multicenter Retrospective Study in Japan. Horm Res Paediatr 2019; 92:45-51. 
18. Rabbiosi S, Vigone MC, Cortinovis F, et al. Congenital hypothyroidism with eutopic thyroid gland: Analysis of clinical and biochemical features at diagnosis and after re-evaluation. I Clin Endocrinol Metab 2013; 98:1395-402.

19. Tamam M, Adalet I, Bakir B, et al. Diagnostic spectrum of congenital hypothyroidism in Turkish children. Pediatr Int 2009; 51:464-8.
20. Pezzuti IL, Lima PP, Dias VM. Congenital hypothyroidism: the clinical profile of affected newborns identified by the Newborn Screening Program of the State of Minas Gerais, Brazil. J Pediatr (Rio J) 2009; 85:72-9. 